\title{
Effect of CuO loading on Structural Properties of $\mathrm{ZnO}$
}

\author{
M. K. Deore \\ Material Research Laboratory, Department of Physics, M. V. P. Samaj's, Arts, Science and Commerce College, Ozar (Mig) 422206, \\ India
}

\begin{abstract}
Copper Chloride $\left(\mathrm{CulCl}_{2} .2 \mathrm{H}_{2} \mathrm{O}\right)$ (Hexahydrate) powder of different weight percent (1 3, 5 and 7 wt \%) where loaded in Analar Reagent grade (99.9 \% pure) ZnO powder by mixing mechnochemically in acetone medium. The prepared materials were sintered at $1000^{\circ} \mathrm{C}$ for $12 \mathrm{~h}$ in air ambience and ball milled to ensure sufficiently fine particle size. The structural properties of the powder materials were investigated by $X$-ray diffraction analysis. The observed powder materials show the polycrystalline nature and the crystallite size found to be in the range of 23 to $35 \mathrm{~nm}$. The lattice parameters of all powder samples were determined.
\end{abstract}

Keywords: $\mathrm{ZnO}, \mathrm{CuO}, \mathrm{XRD}$, Crystallite size, d-spacing, Lattice constants

\section{Introduction}

A composite material is a material made from two or more constituent materials with significantly different physical or chemical properties that, when combined, produce a material with characteristics different from the individual components. More recently, researchers have also begun to actively include sensing, actuation, computation and communication into composites, [1]. CuO-ZnO Composite structures having Optoelectronics, Sensing and Catalytic Applications.

$\mathrm{ZnO}$ is a II-VI group compound semiconductor with a hexagonal wurtzite crystal structure. It has a wide and direct band gap of $3.37 \mathrm{eV}$ at $300 \mathrm{~K}$ and a large free exciton binding energy of $60 \mathrm{meV}$. It has unique physical and chemical properties, low-dimensional volume, high aspect ratio, light-matter interaction, cost-effectiveness and can be synthesized by various chemical and physical methods $\mathrm{ZnO}$ has become one of the most popular materials for electrical and optical applications over the time. It is promising material for many optoelectronic applications such as ultraviolet lasers, light-emitting diodes, $\mathrm{p}-\mathrm{n}$ junction devices, thin-film transistor, solar cells, acoustic devices, chemical and biological sensors, areas like SAW devices, varistors, transparent electrodes, gas sensors[2-15].

On the other hand, cupric oxide $(\mathrm{CuO})$ is p-type semiconductors having band gap energy of 1.21 to $1.51 \mathrm{eV}$. $\mathrm{CuO}$ is an attractive material for photovoltaic applications since it has advantages of a relatively high absorption coefficient in the visible region, low cost production, and is non-toxic. $\mathrm{CuO}$ has been established as a number of applications like in various fields such as dye sensitized solar cells, gas sensors, bio-sensors, nanofluid, photo detectors, energetic materials (EMs), field emissions, super capacitors, removal of inorganic pollutants, photo catalysis and magnetic storage media, gas sensors, solar photovoltaic, lithium ion electrode etc[16-27].

In order to obtain better crystallization quality and better optical and electrical properties, researchers have performed doping in metal oxides. Doping of the base martial was carried out by adding the additives in the base material. Zinc is an important transition metal element and $\mathrm{Zn}^{2+}$ has close ionic radius parameter to that of $\mathrm{Cu}^{2+}$, which means that $\mathrm{Zn}$ can easily penetrate into $\mathrm{CuO}$ crystal lattice or substitute $\mathrm{Cu}$ position in the crystal $[28,29]$.

\section{Experimental Procedure and Results}

\subsection{Synthesis of composite material}

$\mathrm{CuO}$ - $\mathrm{ZnO}$ composite material were obtained by adding the Copper chloride $\left(\mathrm{CuCl}_{3} \cdot 6 \mathrm{H}_{2} \mathrm{O}\right)$ (Hexahydrate) powder of different weight percent $(0.5,13,5$ and 7 wt \%) with Analar Reagent grade (99.9\% pure) $\mathrm{ZnO}$ powder by mixing mechnochemically in acetone medium. The prepared materials were sintered at $1000 \mathrm{oC}$ for $12 \mathrm{~h}$ in air ambience and ball milled to ensure sufficiently fine particle size.

\section{Physical Characterization}

\subsection{Structural analysis}

In order to understand the structural properties of pure $\mathrm{ZnO}$ and $\mathrm{CuO}$ loaded $\mathrm{ZnO}$ powder materials at different doping concentration, X-ray diffraction analysis of these sintered powders were carried out using $\mathrm{Cuk} \alpha$ radiation

Fig. 1 (a- e) shows the XRD pattern of unloaded- $\mathrm{ZnO}$ and $\mathrm{CuO}$ loaded $\mathrm{ZnO}$ composite material with different doping concentration concentrations. The observed diffraction peaks correspond to the hexagonal wurtzite structure of $\mathrm{ZnO}$ (JCPDS 76-0704) and monoclinic phase of CuO (JCPDS 221107). The observed $\mathrm{ZnO}$ phase has preferred orientation in (101). The sharp peaks of XRD are corresponds to $\mathrm{ZnO}$ and $\mathrm{CuO}$ materials and are observed to be polycrystalline in nature. The higher peak intensities of an XRD pattern are due to the better crystallinity. 


\section{International Journal of Science and Research (IJSR) \\ ISSN (Online): 2319-7064}

Index Copernicus Value (2013): 6.14 | Impact Factor (2015): 6.391

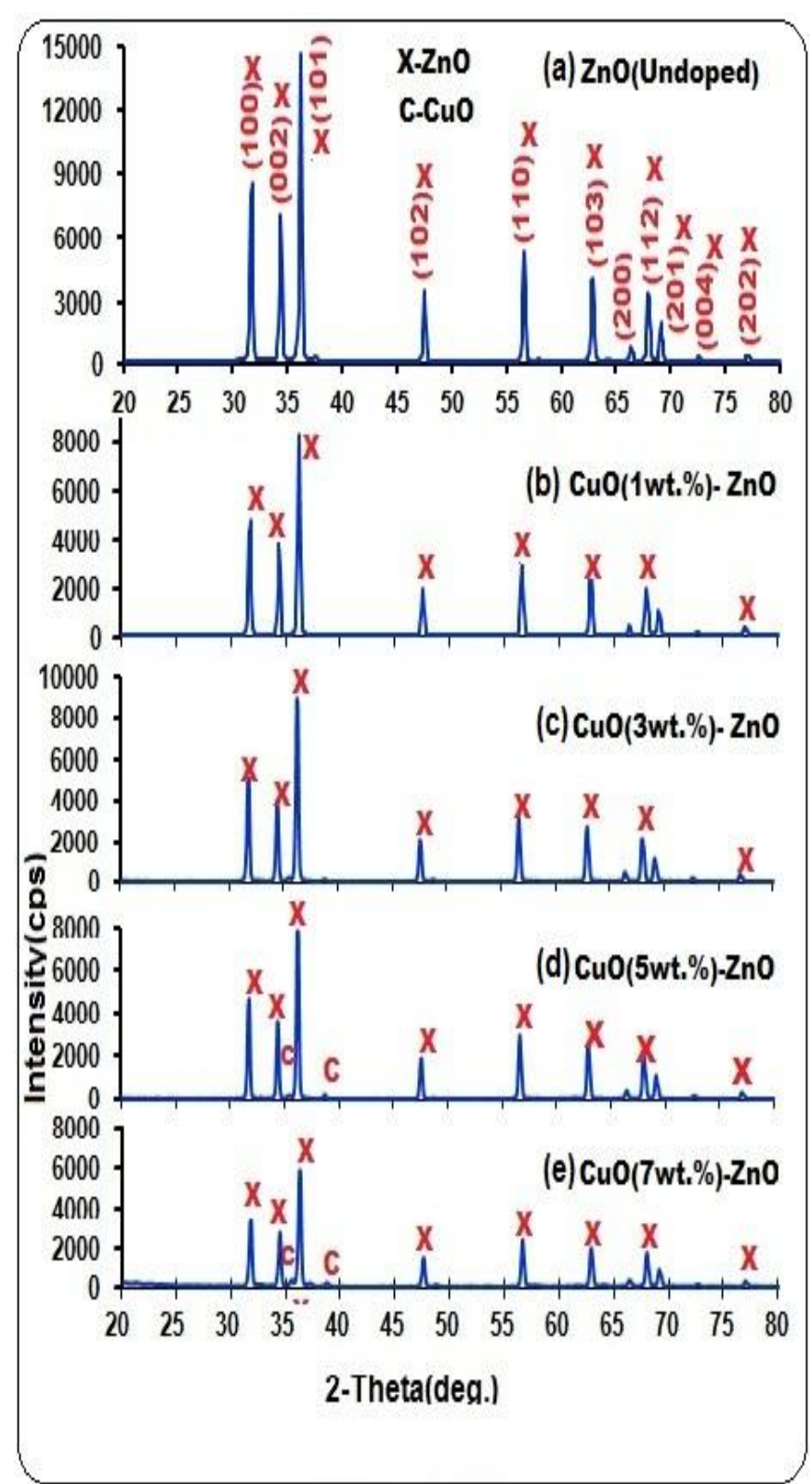

Figure 1: $\mathrm{XRD}$ pattern pure $\mathrm{ZnO}$ and $\mathrm{CuO}$ loaded $\mathrm{ZnO}$ composite material.

Fig. 1(b, c) shows that the in the XRD pattern of $\mathrm{CuO}$ loaded $\mathrm{ZnO}$ composite materials (1 and 3 wt. \%) there was no prominent peaks of $\mathrm{CuO}$ are observed. It is due to low concentration of dopant as compared to base material $(\mathrm{ZnO})$. Also it implies that copper atoms replace zinc in the hexagonal lattice and/or copper segregate to the noncrystalline region in the grain boundary [30].

Fig. $1(\mathrm{~d}, \mathrm{e})$ shows that the in the XRD pattern of $\mathrm{CuO}$ loaded $\mathrm{ZnO}$ composite materials (5 and 7 wt. \%) the some traces of $\mathrm{CuO}$ are present in it. It may indicate that the solid solubility of $\mathrm{Cu}$ in $\mathrm{ZnO}$ has been exceeded. $\mathrm{CuO}$ peaks of corresponding to the planes (002) and (111) are observed.

The average crystallite size was calculated from XRD data based on Debye Scherer's formula equation $(5.1)$ [31, 32].

Where

$$
\mathrm{D}=\frac{0.9 \lambda}{\beta \operatorname{Cos} \theta}
$$

D- is average crystallite size, $\beta$ - is the broadening of the diffraction line measured at half maximum intensity(FWHM)

$\lambda$-is wavelength of the $\mathrm{x}$ - ray radiation and $(0.1542 \mathrm{~nm})$.

$\theta$ - is the Bragg angle

The d-spacing of the planes corresponding to the different observed peaks, FWHM, crystallite size and hkl-planes of the pure $\mathrm{ZnO}$ and $\mathrm{CuO}$-loaded $\mathrm{ZnO}$ materials are listed in Table 1

Table 1: XRD data of pure $\mathrm{ZnO}$ and $\mathrm{CuO}$ loaded $\mathrm{ZnO}$ composite materials

\begin{tabular}{|c|c|c|c|c|c|c|}
\hline $\begin{array}{c}\text { Doping } \\
\text { level }\end{array}$ & $\begin{array}{c}\text { Sr. } \\
\text { No. }\end{array}$ & $\begin{array}{c}2 \theta \\
(\text { deg. })\end{array}$ & $\begin{array}{c}\text { Observed } \\
\text { - Spacing } \\
(\AA)\end{array}$ & $F W H M$ & $\begin{array}{c}\text { Crystallite } \\
\text { Size } \\
D(\text { nm })\end{array}$ & $\begin{array}{c}\text { Planes } \\
(\text { hkl })\end{array}$ \\
\hline \multirow{2}{*}{ Pure $\mathrm{ZnO}$} & 1 & 31.70 & 2.82 & 0.265 & 35 & $\mathrm{Z}-100$ \\
\cline { 2 - 7 } & 2 & 76.90 & 1.22 & 0.422 & 27 & $\mathrm{Z}-202$ \\
\hline $\begin{array}{c}1 \mathrm{wt} \% \mathrm{CuO} \\
\text { loading }\end{array}$ & 1 & 31.70 & 2.82 & 0.267 & 34 & $\mathrm{Z}-100$ \\
\cline { 2 - 7 } & 2 & 76.90 & 1.24 & 0.436 & 26 & $\mathrm{Z}-202$ \\
\hline $\begin{array}{c}3 \mathrm{wt} \% \mathrm{CuO} \\
\text { loading }\end{array}$ & 1 & 31.70 & 2.82 & 0.276 & 33 & $\mathrm{Z}-100$ \\
\hline \multirow{2}{5}{$\begin{array}{c}5 \mathrm{wt} \% \mathrm{CuO} \\
\text { loading }\end{array}$} & 1 & 31.80 & 2.81 & 0.259 & 35 & $\mathrm{Z}-100$ \\
\cline { 2 - 7 } & 2 & 76.90 & 1.23 & 0.423 & 27 & $\mathrm{Z}-202$ \\
\hline $\begin{array}{c}7 \mathrm{wt} \% \mathrm{CuO} \\
\text { loading }\end{array}$ & 1 & 31.70 & 2.81 & 0.299 & 31 & $\mathrm{Z}-100$ \\
\cline { 2 - 7 } & 2 & 76.90 & 1.23 & 0.496 & 23 & $\mathrm{Z}-201$ \\
\hline
\end{tabular}

Table 1 shows the variation of crystallite size of pure $\mathrm{ZnO}$ and $\mathrm{CuO}$ loaded $\mathrm{ZnO}$ composite material with different concentration of dopant. It has been observed that the increased dopant concentration decreases in crystallite size. Slightly broadening of diffraction lines may be attributed to small crystalline effects or chemical heterogeneity of the samples. For planes and (202) the crystallite size decreases.

From the XRD pattern, the lattice constants of hexagonal $\mathrm{ZnO}$ phase in all doping concentrations can be calculated using the equation $[31,32]$

$$
\frac{1}{\mathrm{~d}_{(\mathrm{hkl})}^{2}}=\left(\frac{4}{3}\right) \times\left(\frac{\left(\mathrm{h}^{2}+\mathrm{hk}+\mathrm{k}^{2}\right)}{\mathrm{a}^{2}}\right)+\frac{\mathrm{l}^{2}}{\mathrm{c}^{2}}
$$

Where ' $d$ ' is interplanar distance,

$$
\frac{c}{a}=\sqrt{\frac{8}{3}}
$$

'a' and 'c' are lattice constants.)(Being hexagonal structure).

Table 2: Lattice constants of pure and $\mathrm{CuO}$ loaded $\mathrm{ZnO}$

\begin{tabular}{|c|c|c|c|c|c|}
\hline Phase & $\begin{array}{c}h k l- \\
\text { Plane }\end{array}$ & $2 \theta$ & $d(\AA)$ & $a(\AA)$ & $c(\AA)$ \\
\hline $\mathrm{ZnO}($ Pure $)$ & 202 & 76.90 & 1.2237 & 3.199 & 5.224 \\
\hline $\mathrm{ZnO}-\mathrm{CuO}(1 \mathrm{wt} \%)$ & 202 & 76.90 & 1.2388 & 3.238 & 5.288 \\
\hline $\mathrm{ZnO}-\mathrm{CuO}(3 \mathrm{wt} \%)$ & 202 & 76.90 & 1.2393 & 3.240 & 5.290 \\
\hline $\mathrm{ZnO}-\mathrm{CuO}(5 \mathrm{wt} \%)$ & 202 & 76.90 & 1.2372 & 3.234 & 5.281 \\
\hline $\mathrm{ZnO}-\mathrm{CuO}(7 \mathrm{wt} \%)$ & 202 & 76.90 & 1.2379 & 3.236 & 5.284 \\
\hline
\end{tabular}

The calculated values of lattice constants are given in Table 2 , From the Table 2, it has been observed that there is variation of lattice constants from JCPDS value $(\mathrm{a}=3.25 \AA$, $\mathrm{c}=5.207 \AA$ ) of $\mathrm{ZnO}$. The slight increase in lattice parameter

\section{Volume 5 Issue 6, June 2016} www.ijsr.net 


\section{International Journal of Science and Research (IJSR) \\ ISSN (Online): 2319-7064}

Index Copernicus Value (2013): 6.14 | Impact Factor (2015): 6.391

revealed that the ionic size of tetrahedrally coordinated $\mathrm{Cu}^{2+}$ is larger than $\mathrm{Zn}^{2+}$. The reason of increment may be due to the nonuniform substitution of $\mathrm{Cu}$ ion into the $\mathrm{Zn}$ site as the radius of $\mathrm{Cu} 2+$ ion is smaller than the $\mathrm{Zn}^{2+}$ ion $[33,34]$.

\section{Summary and Conclusions}

From the results obtained, following conclusions can be made;

i) It shows that the $\mathrm{CuO}-\mathrm{ZnO}$ functional material can be obtained by mechanochemical method.

ii) The XRD analysis shows that the observed powder materials show the polycrystalline nature and the variation in the crystallite size due to doping. The crystallite size was found to be in the range of 23 to 35 nm.

iii) It has been observed that there is variation of lattice constants from JCPDS value ( $\mathrm{a}=3.25 \AA$, $\mathrm{c}=5.207 \AA$ ) of $\mathrm{ZnO}$. The slight increase in lattice parameter revealed that the ionic size of tetrahedrally coordinated $\mathrm{Cu}^{2+}$ is larger than $\mathrm{Zn}^{2+}$. The reason of increment may be due to the nonuniform substitution of $\mathrm{Cu}$ ion into the $\mathrm{Zn}$ site as the radius of $\mathrm{Cu}^{2+}$ ion is smaller than the $\mathrm{Zn}^{2+}$ ion

iv) $\mathrm{CuO}$ loaded $\mathrm{ZnO}$ functional material would be used for the preparation of thick films and thick films would be use full for gas sensing application.

\section{Acknowledgment}

The author (MKD) is very much thankful to The Sarchitnis, Smt. Nilimatai Pawar, M. V. P. Samaj, Nashik, Dr. V. B. Gaikwad, Director, B.C.U.D. Savitribai Phule Pune University, Dr. G. H. Jain, Principal, Chandwad College for his keen interest in this research.

\section{References}

[1] M. A. Mc Evoy and N. Correll. "Materials that couple sensing, actuation, computation and communication". Science 347(6228), 2015.

[2] C. Klingshirn, "ZnO: Material, Physics and Applications" Chem PhysChem, 8(6): p. 782-803, 2007.

[3] D. R. Lide, "CRC Handbook of Chemistry and Physics". 82 ed., LLC: CRC Press. 4-134, 2001/2.

[4] C. W. Bunn, "The lattice-dimensions of zinc oxide". Proceedings of the Physical Society, 47(5): pp. 835$842,1935$.

[5] S. Ilican, M. Caglar, Y. Caglar, "Sn doping effects on the electro-optical properties of sol gel derived transparent ZnO films".Appl. Surf. Sci., 256 (23), pp.7204-7210, 2010

[6] J. B. Lee, H. J. Lee, S. H. Seo, J. S. Park, "Characterization of undoped and $\mathrm{Cu}$-doped $\mathrm{ZnO}$ films for surface acoustic wave applications", Thin Solid Films 398-399, pp. 641-646, 2001.

[7] R. I. Lavrov, A. I. Ivon, I. M. Chernenko, "Comparative characteristics of silver and copper electrodes on $\mathrm{ZnO}$ varistor ceramics", J. Eur. Ceram. Soc. (24), pp. 2591, 2004.
[8] Y. Ohya, H. Sakai, Y. Takahashi, "Preparation of transparent, electrically conducting $\mathrm{ZnO}$ film from zinc acetate and alkoxide", J. Mat. Sci. (29), pp. 4099-4103, 1994.

[9] F. C. Lin, Y. Takao, Y. Shimizu, M. Egashira, "Hydrogen-sensing mechanism of zinc oxide varistor gas sensors", Sens. Actuators B (25), pp. 843, 199.

[10] A. Turner, G. Wilson, I. Kaube, Biosensors: Fundamentals and Applications. Oxford, UK: Oxford University Press. pp. 770, 1987.

[11] D. R. Clarke, Varistor Ceramics. J.Am.Ceram. Soc., 82(3): pp. 485-502, 1999.

[12] D. C Look, D. C. Reynolds, J. R. Sizelove, R. L. Jones, , "Electrical properties of bulk ZnO". Solid State Communications, 105(6): pp. 399- 401, 1998.

[13] M.S. Wu, A. Azuma, T. Shiosaki, A. Kawabata, “ Low-loss $\mathrm{ZnO}$ optical waveguides for SAW-AO applications", IEEE Trans. Ultrasonics Ferroelec.Freq Control (36), pp. 442-445, 1989.

[14] M. K. Jayaraj, A. Antony, M. Ramachandran, "Transparent conducting zinc oxide thin film prepared by off-axis RF magnetron sputtering", Bull. Mater. Sci. (25), pp. 227-230, 2002.

[15] K. Keis, C. Bauer, G. Boschloo, A. Hagfeldt, K. Westermark, H. Rensmo, H. Siegbahn, "Nanostructured $\mathrm{ZnO}$ electrodes for dye-sensitized solar cell applications", J. Photochem. Photobiol. A: Chem. (148), pp. 57-64, 2002.

[16] R. N. Mariammal, K. Ramachandrana, G. Kalaiselvan, S. Arumugam, B. Renganathan, and D. Sastikumar, "Effect of magnetism on the ethanol sensitivity of undoped andMn-doped $\mathrm{CuO}$ nanoflakes”. Appl. Surf. Sci., (270), pp. 545- 552, 2013.

[17] M. Hübner, C. E. Simion, Tomescu-St anoiu A., S. Pokhrel, N. Bârsan, and U. Weimar, "Influence of humidity on $\mathrm{CO}$ sensing with p-type $\mathrm{CuO}$ thick film gas sensors". Sensor Actuat B, (153), pp. 347-353, 2011.

[18] Manish Kumar Verma, Vinay Gupta, "A highly sensitive $\mathrm{SnO}_{2}-\mathrm{CuO}$ multilayered sensor structure for detection of $\mathrm{H}_{2} \mathrm{~S}$ gas". Sensor Actuat B, 166- 167, pp. 378-385, 2012.

[19] S. Chandrasekaran, "A novel single step synthesis, high efficiency and cost effective photovoltaic applications of oxidized copper nano particles". Sol Energ Mat Sol C, (109), pp.220-2262013.

[20] J. Morales, L. Sanchez, F. Martın, J. R. RamosBarradob, and M. Sanchez, "Use of low-temperature nanostructured $\mathrm{CuO}$ thin films deposited by spraypyrolysis in lithium cells". Thin Solid Films, (474), pp 133-140, 2005.

[21] K. Santra, C. K. Sarkar, M. K. Mukherjee, B. Ghosh, "Copper oxide thin films grown by plasma evaporation method", Thin Solid Films 213 (2), pp.226-229, 1992.

[22] D. M. Fernandes, R. Silva, A. A.W. Hechenleitner, .E Radovanovic, MAC Melo, "Synthesis and characterization of $\mathrm{ZnO}, \mathrm{CuO}$ and a mixed $\mathrm{Zn}$ and $\mathrm{Cu}$ oxide", Materials Chemistry and Physics 115 (1), pp. 110-115, 2009.

[23] M. Frietsch, F. Zudock, J. Goschnick and M. Bruns, " $\mathrm{CuO}$ catalatic membrane as selective trimmer for metal oxide gas sensor", Sensors Actuators B (65), pp. 379, 2002. 


\section{International Journal of Science and Research (IJSR) \\ ISSN (Online): 2319-7064}

Index Copernicus Value (2013): 6.14 | Impact Factor (2015): 6.391

[24] M. Vaseem, A. Umar, Y. B. Hahn, D. H. Kim, K. S. Lee, J. S. Jang, J. S. Lee, "Flower-shaped CuO nanostructures: Structural, photocatalytic and XANES studies", Catalysis Communications 10 (1), pp.11-16, 2008.

[25] S.B.B. Wang, C.H.H.Hsiao, S J J Chang, K.T.T.Lam, K. H. H. Wen, S. C. C. Hung, "A $\mathrm{CuO}$ nanowire infrared photo detector. Sensor" Actuat A: Phys, (171), pp. 207-11, 2011.

[26] J. Liu, J. Jin, Z. Deng, S. Z. Huang, Z. Y.Hu, L. Wang, "Tailoring $\mathrm{CuO}$ nanostructures for enhanced photo catalytic property". J Colloid Interface Sci., (384), pp.1-9, 2012.

[27] S. C. Ray, "Preparation of copper oxide thin film by the sol- gel-like dip technique and study of their structural and optical properties", Solar Energy Materials \& Solar Cells 68\3-4, pp. 307-312, 2001.

[28] Ahmed M. Nawar1, , Nadia Abdel Aal, Nariman Said, Farid El-Tantawy, F. Yakuphanoglu, "Improving the optical and electrical properties of Zinc Oxide thin film by Cupric Oxide dopant, IOSR Journal of" Applied Physics (IOSR-JAP), Volume 6, Issue 4 Ver. II, pp. 1722, Jul-Aug. 2014.

[29] Bikramkeshari Das, Tanushree Das, Kajal Parashar, S.K.S.Parashar, "Synthesis, Structural and Electrical Properties of $\mathrm{Cu}$ doped $\mathrm{ZnO}$ nanoparticles", Applied Science and Advanced Materials International Vol. 1 (1), pp. 16-20, September 2014.

[30] F. Apaydin, H. Ozkan Toplan, K.Yildiz, "The effect of $\mathrm{CuO}$ on the grain growth of $\mathrm{ZnO}$ ”, Journal of Materials Science, (40), pp. 677, 2005

[31] B. D. Cullity, Elements of X-ray Diffraction, 2nd Edition, Addition Wesley, 1970.

[32] H. P. Klug, L. E. Alexander, X-Ray Diffraction Procedures for Polycrystalline and Amorphous Materials, Wiley, New York, 1974.

[33] Preetam Singh, Ashvani Kumar, Ajay Kaushal, Davinder Kaur, Ashish Pandey and R N goyal, "In situhigh temperature XRD studies of $\mathrm{ZnO}$ nanopowder prepared via cost effective ultrasonic mist chemical vapour deposition" Bull. Mater. Sci., Vol. 31, No. 3, pp. 573-577, June 2008 .

[34] C. West, D.J. Robbins, P.J. Dean, W. Hays, "The luminescence of copper in zinc oxide", Physica B \& C (116), pp. 492-499, 1983.

\section{Author Profile}

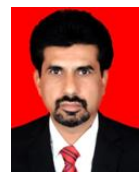

M. K. Deore (India) is currently an Associate Professor of Physics at M. V. Samaj's, Arts, Science and Commerce, College, Ozar(Mig), India. $\mathrm{He}$ received his M. Sc. degree in Physics and Ph. D. degree from the Savitribai Phule Pune University, Pune, India. He has 27 years of teaching experience. He is recognized guide for M. Phil of Savitribai Phule Pune University. His areas of interest are nanomaterial and metal oxide semiconductor gas sensor. He has published 24 research articles extensively on the above topics in various refereed International Journals and book chapters. He has reviewed the research papers for International Journals Sensor Review, Sensor Letters, Journal of Advanced Physics, Material Science.He has presented 22 research articles in International, National and state level conferences held at Stony Brook University, Long Island, New York State, USA (2015), Palmerston North New Zealand (2011), Tainan (Taiwan),
Shilong (Meghalaya), Kolkata(W.B.), Bhopal(U.P.), Amritsar (Panjab, ), Chennai(Tamilnadu, ), Mumbai(M.S.), He has organized one State level and one National level conference at A. S. C. College, Ozar (Mig)(India). He has received best paper presentation award in Indian Science Congress held at Shilong(Meghalaya) in 2009 and $2^{\text {nd }}$ best paper presentation award in National Conference on Development of Electronic Materials and Their Applications held at Shivaji University, Kolhapur, 6-8, 1995. 